\title{
Exhibiting Refugee Routes: Contemporary Collecting as Memory Politics
}

\author{
Randi Marselis
}

\begin{abstract}
In recent years, numerous European museums have collected objects related to refugees. This article examines the Flight for Life (På Flugt) exhibition (2017), which the National Museum of Denmark organized based on a contemporary collecting project that took place in Greece and Denmark in 2016. Alison Landsberg's concept of prosthetic memory is made use of here to examine how the exhibition invited visitors to identify with refugees. This empathetic approach had political potential by promoting solidarity with refugees. However, it did not open up a broader contextualization of the collected objects in terms of the migration policies of Denmark and the European Union. This article argues that museums, through contemporary collecting projects of the refugee reception crisis, engage in memory politics by framing how Europeans will be able to make sense of the refugee reception crisis of the early twenty-first century.
\end{abstract}

Key words: Refugees, contemporary collecting, prosthetic memory, Europe, Denmark

\section{Introduction}

In recent years, numerous European museums have collected objects related to the so-called European refugee crisis. The collecting of objects, especially boats from the Italian island of Lampedusa, has been taking place for at least a decade (De Angelis 2013; Cimoli 2016; Horsti 2016, 2019b). Scandinavian museums have also engaged in collecting objects on the topic of undocumented migration, especially when, in 2015, Syrian refugees began to arrive in Scandinavian countries in their multitudes and through unconventional channels (Nikolić 2017; Colding et al. 2018). In Denmark, the public visibility of the crisis peaked in the fall of 2015, when groups of refugees reached Danish borders and continued their journey by walking on Danish highways - many of them with the objective of reaching Sweden. Images of refugees walking on highways, where no pedestrians are allowed, were circulated widely in Danish media and have since become iconic in the Danish representation of the crisis. The National Museum of Denmark reacted to the increased visibility of refugees by initiating a contemporary collecting project in 2016 in both Greece and Denmark. Based on this project, they created the Flight for Life exhibition.

In order to examine the empathetic and representational strategies chosen for Flight for Life, I will draw on Alison Landsberg's concept of prosthetic memory and show how the collected objects and media materials were consistently used to invite visitors to identify with refugees. While the museum staff carefully presented the exhibition as a 'neutral' representation of the refugee reception crisis, I argue that the prosthetic memories created in the exhibition held political potential by promoting solidarity with the refugees. However, I will also discuss the limitations of the museum's use of prosthetic memory as an exhibition strategy, as the empathetic position promoted in the exhibition did not in itself lead to a broader contextualization of the collected objects, in terms of explaining the darker aspects of the migration policies of Denmark and the European Union (EU), including deportations, the criminalization of humanitarian help and the creation of dangerous refugee routes. As an example, I focus on a collected rubber dinghy that could have been used to represent the 
criminalization of humanitarian help but was not. The reason, I argue, is that it would have been quite difficult for a Danish museum to present these perspectives in Denmark's current political climate. This is not to say that the collected objects could not be used in future exhibitions that include more contentious themes. It is for this reason that, while this article mainly focuses on the Flight for Life exhibition, it also argues that museums collecting and exhibiting objects related to refugees engage in memory politics by framing how Europeans will be able to make sense of the refugee reception crisis of the early twenty-first century.

\section{Museums and the refugee reception crisis}

Following Karina Horsti (2019a), I will refer to the crisis as 'the European refugee reception crisis', thus acknowledging that the crisis was not created by refugees but was rather a 'crisis of reception - a result of the inability to respond to wars, dictatorships, and disasters in a sustainable way' (Horsti 2019a: 3). In media and public debates, the crisis is often described as a 'sudden emergency appearing from nowhere' (Horsti 2019a: 2). This effectively erases the roles that EU states played in the deadly 'push factors' in the Middle East and in creating dangerous refugee routes, creating a form of selective amnesia. This is again likely to have consequences for the sense of responsibility that EU citizens have towards the fates of refugees. Media representations and debates about the refugee reception crisis tend to be ahistorical and are not linked to European experiences of war and flight (Horsti 2019a). However, as memory institutions, museums have the potential to include the current crisis in national and European memory cultures. Maria Vlachou, for example, has examined the various positions taken up by museums that choose to represent migration. While she showed that these positions range from claiming neutrality to overt activism, she nevertheless acknowledged just how difficult it is to work with the issue in the contemporary political climate:

Considering how divisive the issues of migration and the refugee crisis have been in many countries (and how political campaigns and political decisions have put them at the heart at their rhetoric), I have been heartened to see different types of museum exploring connections to migration and seeking to open up opportunities to reflect on this subject from different angles (Vlachou 2019: 48).

The point of Vlachou's analysis is to propose that museums be developed into 'empathetic spaces' that provide room for opposing views and encourage respectful dialogue (Vlachou 2019: 54). Doing so, she proposes, opens up the possibility that museums could directly engage with political debates through exhibitions and events.

This article presents my own analysis of these issues, based on observations made in the Flight for Life exhibition at the National Museum in spring 2017. In addition to noting my own multisensorial encounters with objects and media materials (Dudley 2010), I made a thorough photo documentation of the exhibition. I also collected newspaper articles about the collecting process and the exhibition, and gained valuable information through an interview with Gitte Engholm, the curator of the exhibition. ${ }^{1}$ Furthermore, I drew on publications written about the collecting project by the museum staff (Engholm et al. 2018; Colding et al. 2018). In order to examine how some perspectives related to the collected objects (in particular a rubber dinghy) were toned down in the exhibition, I found additional material in Danish and international media regarding the work of humanitarian organizations and EU bordering politics.

The following section will present a general introduction to contemporary collecting as well as the collecting project at the Danish National Museum. I will then describe the tense political situation in which the exhibition was set up and describe the overall layout of the exhibition. This will be followed by a more theoretical section on Landsberg's concept of prosthetic memory which I will then apply to the first section of the exhibition, which represented refugees' crossing of the Mediterranean Sea in order to exemplify how prosthetic memories are promoted in the exhibition. The remainder of the analysis goes beyond the representational strategies of the museum, to examine the limitations of the chosen empathetic approach in terms of contextualizing the objects in relation to more controversial aspects of the refugee reception crisis. 


\section{Contemporary collecting as memory politics}

The purpose of contemporary collecting is to 'preserve the present for the future' (Rhys 2011: 19). A significant number of museums are increasingly using contemporary collecting initiatives to assure their continued relevance to culturally diverse societies:

Collecting contemporary material is influenced by an increased claim made by different groups for the museum space and the democratization of museums, from object-centred institutions, mainly interested in one version of history, to centres responsible for representing society in all its diversity (Rhys 2011: 35).

Collecting necessitates making selections. Thus, the collecting process implies an interpretation of the chosen objects and therefore a memory political framing of the events and issues in question. The choices made during contemporary collecting will to a large extent determine which framings will be available for future exhibitions. Contemporary collecting, also known as 'rapid response' projects, is often established in reaction to pressing challenges such as terror, migration, natural disasters and coexistence in multi-ethnic societies (Rhys and Baveystock 2014). The sensitivities surrounding dramatic events, however, can make it difficult to determine the right time to start collecting objects and testimonies. Furthermore, some events (e.g. terrorist attacks) may not be suitable for an immediate exhibition. Rather, a temporal distance is necessary before a reflective exhibition can be held (Fraser 2014; Kavanagh 2014). Some contemporary issues are particularly likely to divide museum audiences politically, and museums choose different strategies when collecting objects for these issues. For example, the Jewish Museum in Berlin has collected objects related to contemporary forms of antiSemitism. The Museum's deputy director, Léontine Meijer-van Mensch, has stated that since museums are 'never neutral' they should be transparent about supporting specific positions, as in this case with the fight against intolerance. ${ }^{2}$ In contrast to this interpretation of the role of museums, Brenda Malone, curator of the National Museum of Ireland, which collected flags and banners from the abortion referendum in Ireland in 2018, explicitly stated that the museum's position was neutral regarding this matter: 'The museum is nonpolitical, and my job is to research this moment in history, not how I feel about it'. ${ }^{3}$ The museum made sure to collect material from both the 'No' and 'Yes' sides of the referendum and withheld collecting until the morning after the referendum, when the objects could be considered 'historic' material culture. ${ }^{4}$ Although the mere initiative of collecting on the abortion issue could be seen as political, the curator's carefully neutral positioning of this rapid response collecting in media interviews is understandable in a situation where some Irish cultural institutions had experienced criticism for their response to the campaign. According to Geraldine Kendall Adams, ${ }^{5}$ the Arts Council of Ireland had even warned institutions that they risked losing funding if they did not remain impartial.

The Flight for Life (2017) exhibition displayed the objects and stories collected in Greece and Denmark in 2016 by the staff of the National Museum of Denmark. ${ }^{6}$ The project was driven by the idea of collecting for the future and acknowledged that wars, conflicts and the refugee reception crisis of the 2010 s entailed future collective memories. The project was explicitly framed to have a long-term perspective, in that collected 'objects now and in 100 years' time from now document the refugee streams that today reach Europe in the aftermath of wars and conflicts'. In a newspaper article published in May 2016, Gitte Engholm explained that the collecting project was 'also about citizenship and [...] a signal to the Syrian refugees that we would like to know the story - both for the sake of the Danes and for the sake of the new citizens' (Stockmann 2016: 3; author's translation). In a subsequent article, another staff member was of the opinion that 'later it will also be interesting for them [Syrian refugees] that people took an interest in their history as part of the Danish history, just like the Hungarians who arrived in 1956, or the Huguenots who arrived in the eighteenth century' (Termansen 2017: 5; author's translation). Thus, the motivation behind this contemporary collecting project was inclusive with regard to viewing refugees as future citizens, whose descendants (as future Danes) will also wish to see their history represented in the National Museum. When asked by a journalist whether the museum had taken a political stance on refugee issues, Gitte Engholm explained that the museum had made sure to collect items representing different 
positions: 'In that way we represent both citizens who feel motivated to help the refugees, and citizens who are sceptical and feel unsafe' (Stockmann 2016: 3; author's translation). In this sense, the collecting strategy was in line with Vlachou's proposal for museums as 'empathetic spaces' where visitors could encounter opposing views on migration and refugees (Vlachou 2019: 54). However, the approach chosen for the exhibition established immediately after the collecting process was quite different, as it avoided explicit references to the ongoing political debates about the refugee reception crisis.

\section{Exhibiting refugees' routes in a tense political climate}

When the museum staff began collecting objects, the idea of the exhibition had not yet been conceived, but the long-term perspective of collecting for the future may have helped legitimize an exhibition on this contentious and contemporary topic. The exhibition opened in Copenhagen in January 2017 and mainly represented the peak of the crisis in 2015-2016, while also acknowledging that the events were ongoing by including regularly updated information on the global refugee situation.

Danish migration policies have become increasingly harsh in the last few decades, regardless of whether the shifting governments have been led by the Social Democrats or by the right-wing Venstre party. At the time of the exhibition, Venstre was leading a right-wing coalition government with support from the overtly nationalist Danish People's Party (Dansk Folkeparti, DF). In 2015-2016, the increasing numbers of asylum seekers arriving in Denmark had been a particularly hot topic in the Danish public sphere, and disputed measures, such as reinstalling border controls at the border with Germany, had been taken by the Danish government. This tense political climate rendered Flight for Life controversial, and the museum staff issued several disclaimers in the press and on the museum's website announcing that Flight for Life '[was] not an exhibition about the refugee debate and [did] not want to promote a specific agenda'. They added that it was up to 'the individual visitor' to use their discretion and described the purpose of the exhibition as providing visitors with 'information and insight about what it means to be fleeing'. ${ }^{8}$ Thus, the museum explicitly positioned itself as neutral and acknowledged that the topic was divisive among the Danish population. If the museum wanted to avoid alienating potential visitors with anti-migration views, such a neutral stance may have been helpful. However, I argue that this careful neutral positioning of the museum should also be seen in the context of recent, regrettable tendencies in Danish cultural policies.

The Danish National Museum is a state museum and the 'head museum' of all cultural museums in Denmark. It is highly dependent on public funding and since 2016 has been subject to severe cutbacks, resulting in staff redundancies and cancelled exhibitions. Denmark has had a museum law in place since 1958, and public funding is given according to the 'arm'slength' principle, which implies that politicians will not interfere with decisions made by the museums. In 2012, however, the National Museum did experience a media storm when the politician Alex Ahrendtsen, who represents the DF, criticized the decision of the museum to exclude Native American scalps in their temporary Powwow: We Dance, We're Alive exhibition. On this occasion, the Minister of Culture, Uffe Elbæk, from the Danish Social Liberal Party, stressed the importance of the arm's-length principle by expressing his confidence in the professionalism of the museum's staff (Marselis 2016). However, local museums have since experienced media storms initiated by politicians when exhibiting other contentious topics, including blasphemy in art and Danish colonial history.

In a recent report, museum directors warned against a 'shortened arm's-length' (Marker and Rasmussen 2019: 67-8). Moreover, museums may be hesitant to irritate politicians out of fear for both bad publicity and long-term consequences of losing reputation and funding. The claimed neutrality of the National Museum should be understood in the context of these developments in the national cultural sector. ${ }^{9}$ Thus, when the National Museum invited visitors to empathize with the plight of refugees, it may appear as a relatively safe strategy. Nonetheless, opening an exhibition about flight at this particular time and promoting an empathetic position towards refugees was hardly an entirely apolitical choice, and the courage shown by the museum staff when choosing to hold this exhibition should be recognized. The following section will introduce the overall layout of the exhibition before Landsberg's concept of prosthetic memory is presented and applied to this context. 


\section{The Flight for Life exhibition}

The main audience of Flight for Life were Danes, although the exhibition also welcomed tourists and visitors who had a refugee background (Engholm et al. 2018)..$^{10}$ The exhibition continuously invited visitors to imagine the situations that refugees would have found themselves in en route to Denmark. The exhibition's overall narrative was quite linear, consisting of the following seven sections:

1. Risking Your Life (a depiction of the boat crossings)

2. From Place to Place (an illustration of temporary camps in Greece)

3. Order in Chaos (a presentation of the resources of refugees in temporary camps)

4. The Journey (a portrayal of the routes taken)

5. Welcome? (a depiction of the reactions of Danes upon the arrival of refugees)

6. Waiting Time (a presentation of life in Danish asylum centres)

7. A New Home (a representation of a living room, where the television shows an interview conducted with two asylum families in their new homes in Denmark)

This structure of the exhibition was inclusive with regard to the arrival of refugees as future Danes. However, the national framing implied that the stories of those who were denied asylum and deported from Denmark were not as important.

Each of the seven sections included an introductory text followed by a question that encouraged visitors to consider how they themselves would have coped in similar circumstances. For instance, in the third section, Order in Chaos, the refugees' creativity and resilience were demonstrated when living in makeshift camps in Greece. The introductory text invited visitors to think about their own potential for resilience:

You are a human being. You need to feel at home, even when you aren't. You try to create a temporary home among tents, tarpaulins and Euro pallets. You furnish and decorate. You learn new routines. Can you see light in the darkness? ${ }^{11}$

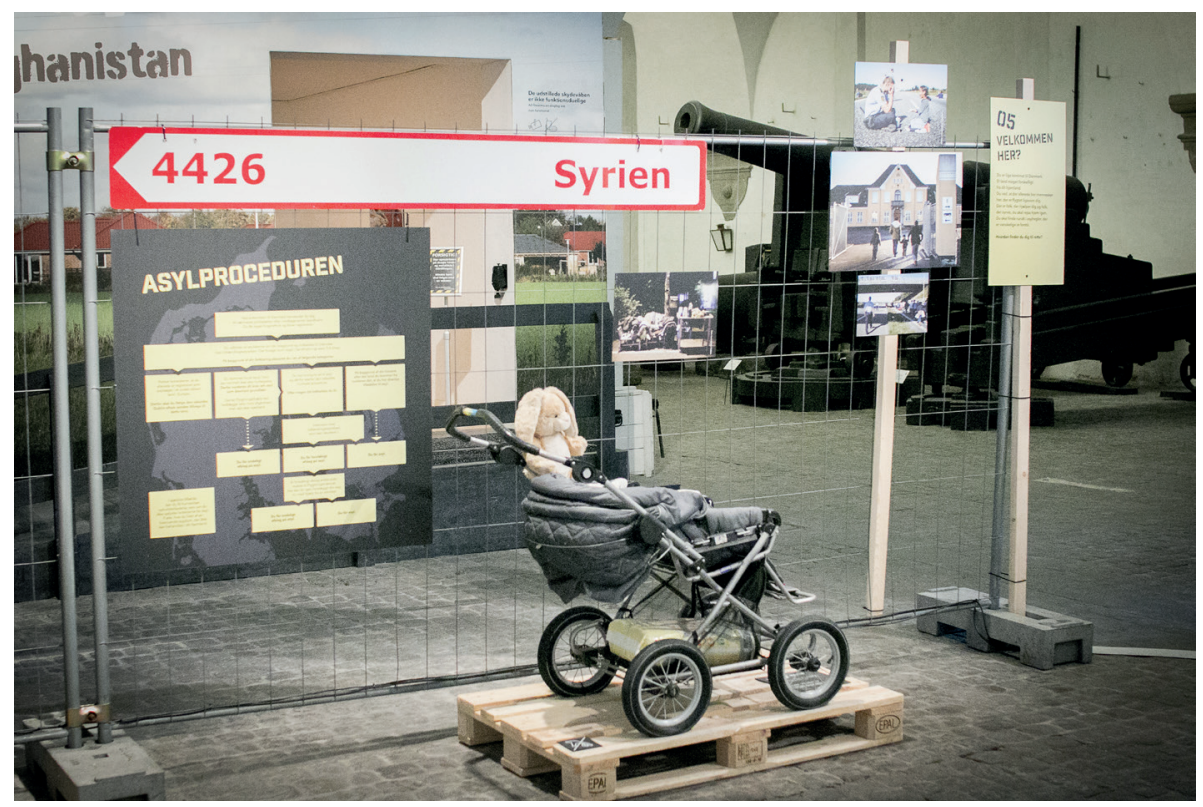

Figure 1. Unofficial sign and pushchair (Photograph taken by Peter Marselis) 
Even in the fifth section, Welcome? which exhibited objects associated with the reactions of Danish people to the arrival of refugees, the perspectives of the arriving refugees were maintained. An installation in this section contrasted a pushchair and a teddy bear donated to a refugee family with an unofficial road sign erected to direct refugees back to Syria. The exhibition text associated with this section read, 'Welcome? You have just arrived in Denmark. [...] There are people who help you and people who think you should go back home' (Figure 1).

When Gitte Engholm first described the intention behind the collecting project, she stated her belief in the ability of original objects to awaken empathy in a way that mere text was unlikely to do (Stockmann 2016). However, it was through the combination of texts, objects and media materials that visitors were positioned as being able to empathetically engage with the experiences of refugees. In order to examine how this empathetic positioning was created in the exhibition, the following section will introduce Alison Landberg's theory of prosthetic memory. Following this, an analysis will be conducted on the first section of the exhibition, Risking Your Life, where the situation at the Mediterranean border was presented.

\section{Prosthetic memory}

In her book Prosthetic Memory, published in 2004, Alison Landsberg argues that museums may serve as experiential sites where visitors, through engagement with mediated representations, are invited 'to take on memories of a past through which they did not live' (Landsberg 2004: 8). Not only does prosthetic memory imply the apprehension of historical narratives but also the personal and emotional engagement with this past in a way that generates empathy towards the fates of those who lived through the events (Landsberg 2004). Prosthetic memory is derived from experiencing different 'pasts' that are not the heritage of one's own family or group, and Landsberg stresses the transportability of this type of memory. Through her analysis of film, television series and museum exhibitions that represented race relations and the Holocaust, Landsberg examines how prosthetic memories hold the potential to 'produce empathy and social responsibility as well as political alliances that transcend race, class and gender' (Landsberg 2004: 21). The concept of prosthetic memory can be successfully applied to the Flight for Life exhibition, which urged Danish visitors, privileged by the safety of their Danish and EU citizenships, to identify with the experiences and precarious situations of refugees. ${ }^{12}$

In 2004, Landsberg described the experiential mode in museums as something new. However, it has since become a mainstream approach to creating engaging museum exhibitions, especially due to the growing use of digital technologies (Arnold-de Simine 2013). The Flight for Life exhibition combined objects, artworks, photographs and videos to create a sensuous experience for visitors. The exhibition also included an immersive, 360-degree video experience, where visitors, through the use of virtual reality headsets, could 'visit' three different locations on the refugee route. Being immersed in the video allowed visitors to witness the intense experience of observing huge piles of discarded life jackets on Lesbos, family life in a refugee camp in Northern Greece and the waiting times for young male asylum seekers in a temporary tent camp in Thisted, Denmark (Colding et al. 2018). ${ }^{13}$ Landsberg repeatedly mentions the bodily aspects of prosthetic memory and describes the experiential mode used in museums as complementing 'the cognitive with affect, sensuousness, and tactility' (Landsberg 2004: 131). Her descriptions of her encounters with objects in the United States Holocaust Memorial Museum, where she noticed the smell emanating from piles of shoes from a Nazi death camp, are similar to the focus on materiality within museum studies, which stress the importance of multisensorial encounters with museum objects (e.g. Dudley 2010). In the Flight for Life exhibition, visitors encountered a pair of boots that had been worn by a Kurdish man from Syria on his journey to Denmark. The sight of the boots was accompanied by incessantly replayed footsteps on gravel, and this sound installation helped me to imagine the hardships of walking long distances in Europe.

Landsberg's use of the bodily metaphor prosthetic - drawing on a prosthesis as an artificial limb - and her associated use of the expression 'taking on memories', have attracted criticism and been interpreted to mean that "people, in fact, "take on" and "experience" the memories and experiences of others' (Berger 2007: 601). This critique prompted Landsberg to clarify her position: 


\begin{abstract}
And yet I am not suggesting that a visitor to the Holocaust Museum believes even for a moment that they are experiencing the Holocaust: visitors don't walk through the freight car and remember being a Holocaust victim. I have in mind something more complicated: because the visitor is having a bodily experience while they are apprehending the intellectual, or cognitive historical narrative that the museum creates, they develop an individual and affective relationship to that particular past (Landsberg 2007: 628).
\end{abstract}

Prosthetic memories are bodily experiences, and this is why they can transform the person, as they 'become part of one's personal archive of experience, informing one's subjectivity' (Landsberg 2004: 26). Following this, said memories may alter our perception of 'the Other' and in the context discussed here, lead us towards more empathetic encounters with refugees.

Landsberg stresses that empathy always acknowledges difference and is a 'way of both feeling for and feeling different from the subject of inquiry' (Landsberg 2004: 135). She contrasts empathy with sympathy which she defines as a simple identification based on a sense of sameness (Landsberg 2004: 149). Thus, prosthetic memory is not a matter of overidentification, and the derived empathy contains both an emotional and cognitive component: 'The connection one feels when one empathizes with another is more than a feeling of emotional connection; it is a feeling of cognitive, intellectual connection, an intellectual coming-to-terms with another person's circumstances' (Landsberg 2004: 149). Landsberg's discussion of empathy was inspired by the writings of Emmanuel Levinas on the ethical connection with 'the Other', where he insists on 'acknowledging rather than obscuring difference' (Landsberg 2004: 151). Landsberg argues that prosthetic memory may enable ethical thinking 'beyond the immediacy of one's own wants and desires' (Landsberg 2004: 149). Following this, Landsberg stresses the political potential of prosthetic memories to produce 'political alliances that transcend race, class and gender' (Landsberg 2004: 21).

If Landsberg is right, the question then becomes in what ways museums can use prosthetic memories to actively contribute to memory politics. This question is not only about how museums can promote specific memory discourses and downplay others but about how they can use this to promote particular forms of empathy. To what extent did Flight for Life promote empathy towards refugees and thereby make future solidarity between groups possible, while also recognizing difference? And if it did, how was this achieved, particularly given its position of neutrality?

One possible clue is provided by Fredrik Svanberg, who argues that museums that aim to represent migration should adopt a multidimensional approach to collected objects - both old and new. This is because 'objects have many potential meanings since they are often connected to many contexts and can always be viewed from many perspectives and interpreted in different ways' (Svanberg 2017: 157). Svanberg's discussion on how to unfold 'migrating objects' has similarities to Igor Kopytoff's (1986) understanding of the cultural biographies of things. Museum staff members are typically well-aware of the complex biographies of objects but rarely 'unfold' them in exhibitions:

The point is not a lack of knowledge, of which there is often plenty; the point is the lack of perspective. Instead of trying to narrow down the imagined essence of an object, its multidimensional character and wide range of connections and relations, its potential infinity of meanings should be acknowledged as a theoretical starting point (Svanberg 2017: 161).

This means that the objects collected by the National Museum could, in theory, be used to present a variety of perspectives on the refugee reception crisis. Doing so might enable a more complex representation of the refugee reception crisis that would include the migration policies of Denmark and other EU states.

The following section zooms in on the first part of the exhibition, which represented the situation on the coast of Lesbos in Greece, in order to explore these issues. The Mediterranean can be described as an intense contact zone, characterized by asymmetrical power relations (Pratt 2008), where refugees encounter local inhabitants, volunteers and professionals from humanitarian organizations and border authorities such as the Greek coastguard. In addition 
to examining how prosthetic memory is stimulated in the exhibitions, one particular object will be focused on - a rubber dinghy - in order to discuss certain aspects of border politics that were not presented in the exhibition.

\section{Exhibiting dangerous crossings}

The Risking Your Life section was introduced by a text that addressed museum visitors as if they were in Turkey contemplating whether to make the dangerous journey to Lesbos by boat:

You have been forced by the war to flee your country. A neighbouring country is safer. But there is no work. No school for the children. No prospect of finding a proper home. Perhaps there is a better future in Europe? Staying is hopeless. To keep fleeing puts your life at risk. What do you choose? (Exhibition text)

The sign bearing this text was placed next to a large photograph of a group of men, women and children in a rubber dinghy. Two young men were wading in front of the dinghy, drawing it towards the beach. ${ }^{14}$ Underneath the photograph, a similar rubber dinghy was exhibited (Engholm et al. 2018). A label placed next to the object read: 'Rubber dinghy. Some refugees sail to Greece in unsafe boats. This rubber dinghy was used by "Team Humanity", formed by Danish volunteers, to help them get safely ashore' (Exhibition text).

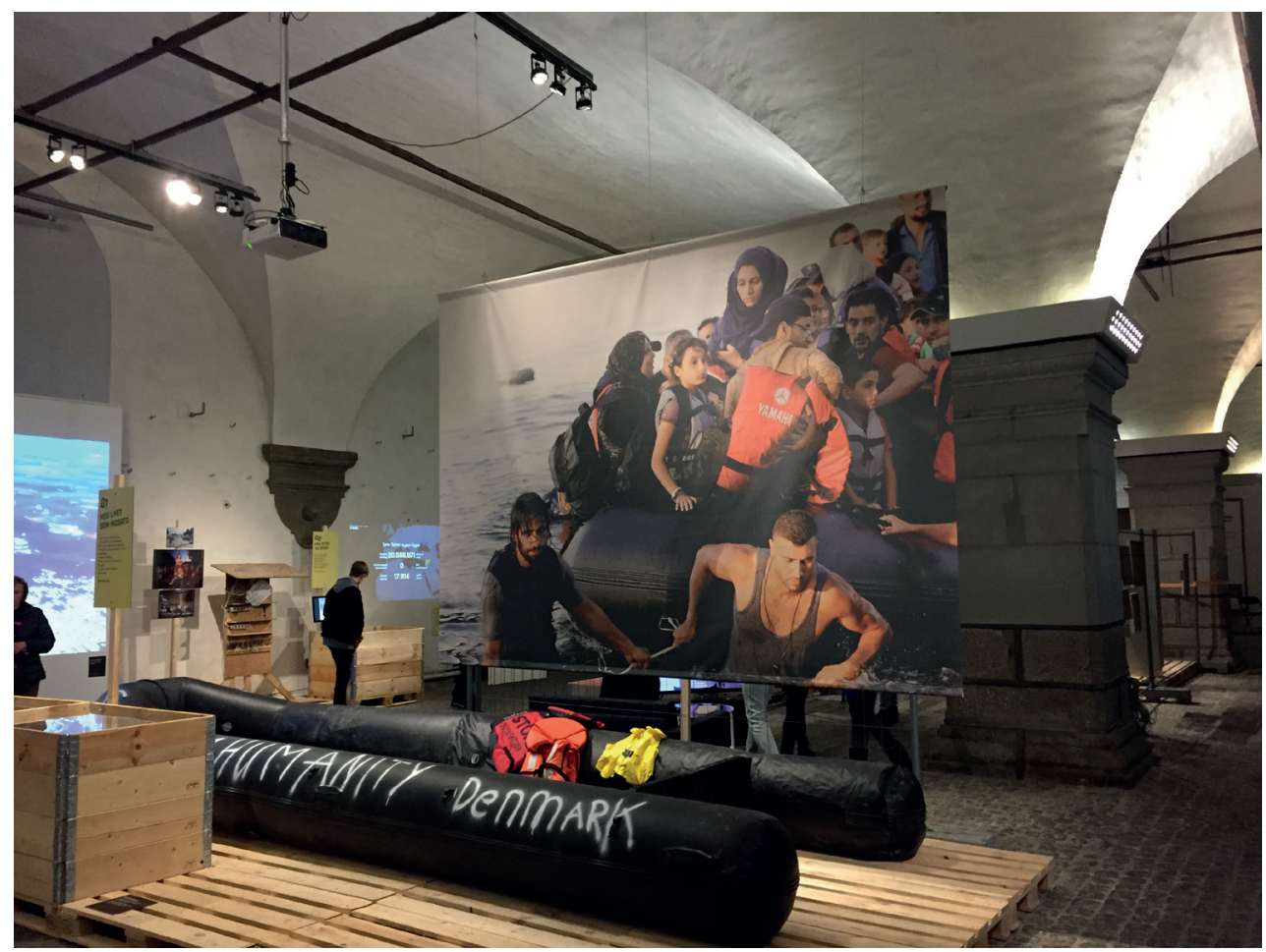

Figure 2. The dinghy at the National Museum of Denmark (Photograph taken by the author)

Humanitarian aid was also represented through mats and blankets provided by the United Nations High Commissioner for Refugees as well as by the reused rescue blankets that had been collected, washed and redistributed by the Dirty Girls organization, which provide help by recycling clothes and blankets found along the shorelines and at transit camps. Moreover, as an example of a sensorial strategy used to create prosthetic memory, visitors were encouraged to wrap themselves in anti-shock foil blankets that were hanging next to a photo of a little girl looking out from such a blanket. 
A few life jackets were placed in the rubber dinghy and one of them was a cheap imitation of a Yamaha model. The accompanying text explained that proper life jackets were expensive and the fake models were regularly produced and sold in Turkey. In the case of this fake Yamaha life jacket, the text read that 'the seams [did] not hold and the contents [were] random foam rubber material' (Exhibition text). The object helped to illustrate the cynicism of individuals who abused the desperate situations of refugees, thereby also depicting the asymmetrical power relations of the contact zone (Pratt 2008).

On the fake life jacket, the words 'Stop Deportation' were stencilled, as the life jacket had been worn at a demonstration in Greece. This element of the object's cultural biography was not pointed out in the exhibition but only mentioned in a newspaper article (Stockmann 2016). Nevertheless, the message was clear, and the refugees' agency in terms of protesting against border policies was also acknowledged by a sign that read: 'To buy your expensive death in rubber casket/To hope the sea will be merciful and not take your soul'. The exhibition text explained that the sign was written by Abdullah Sabouni from Aleppo, Syria, and placed in the EKO refugee camp in northern Greece.

The voices of refugees were also represented via a personal testimonial in the form of a video interview with 19-year-old Jan from Syria. ${ }^{15}$ While sheltering from the rain in a borrowed car, he told his story just one hour after arriving in Lesbos. Thus, both location and timing added to the authenticity of Jan's story. When asked about his dreams, Jan expressed a wish for stability in the form of a home, citizenship and a working passport. His personal dream of getting a passport that would give him greater mobility and a better chance of obtaining a visa to the Schengen Area may be seen as an invitation to Danish visitors to realize the privileges implied in carrying a Danish/EU passport.

A number of personal objects found on the beaches of Lesbos were displayed on a layer of stones. These objects included children's clothes, the cover of a Koran and an identity card carefully placed to hide the identity of the bearer. The text stated, 'how and why these particular things have ended up at the water's edge we do not know' (Exhibition text). One of the objects was a faded pair of tiny jeans. As pointed out by Elizabeth Crooke, 'the materiality of clothing is formed by wear. Worn a certain way by one person rather than another, the item will be shaped to fit and an everyday item becomes unique' (Crooke 2019: 620). Taken to the tiny jeans, this idea reveals the way in which this common garment became an emotive trace of a specific child. The unknown provenance of the jeans reinforced this, making it likely the visitor will wonder about the fate of this specific child and remember widely circulated press photos of drowned children. Exhibiting the tiny jeans resonated with the introductory text to this section of the exhibition, which first positioned the visitor as a parent ('No school for the children') before presenting the dilemma faced by the refugees ('Staying is hopeless. To keep fleeing puts your life at risk. What do you choose?'). Visitors with a Danish majority background would be likely to not only identify with this precarious situation but also feel blessed that they never had to make that choice on behalf of their own children. When the photographs of drowned children started circulating in the Danish media, I encountered people who argued that the parents were acting irresponsibly by bringing their children on this deadly route. ${ }^{16}$ The exhibition invited visitors to identify with the situation of the refugees and form a deeper understanding of their motives.

The sense of pathos conjured by these objects was amplified by the use of video. Next to the collected objects, a short video shot in a small bay on a coast near Dikili - a town in Turkey - was played on repeat. The video began by showing the tranquil, clear water where clothes were adrift and then panned up to show the blue sky and blurry outline of Lesbos on the horizon. As the camera refocused on the island, a text emerged: 'Lesbos, 17 km away'. This looped video footage lent a tranquil yet sinister atmosphere to this section of the exhibition, suggesting the number of drownings that occurred. ${ }^{17}$

As shown above, the collected objects were given context by inserting texts, photographs, and video footage alongside them. In this way, the exhibition clearly invited visitors to identify with the refugees who had risked their lives crossing from Turkey to Lesbos by boat. Although the exhibition focused on the very recent past, it offered a multisensorial experience that had potential for becoming grounded in the visitor's body as a prosthetic memory (Landsberg 2004: 148). The visitors were encouraged to come-to-terms with the refugees' circumstances, while 
reflecting upon their own safe position as Danish and EU citizens, through empathetically 'feeling for, while feeling different from' the refugees (Landsberg 2004: 149). However, the museum stayed clear of politically hot topics related to the role of the EU in the creation of these dangerous routes (Horsti 2019a). This meant that the visitors were not encouraged to reflect upon the broader political situation and understand their own role in the production of the crisis in the first place.

To explore this question further, it is necessary to look more closely at the inclusion of objects from humanitarian aid operations. For while these served as a reminder of the humane encounters that had occurred in Lesbos and elsewhere along the refugee routes, their inclusion did not include the perspectives of volunteers and professionals who had worked for these NGOs. While their perspectives would have shifted attention away from the perspectives of the refugees, this would not necessarily have disrupted the creation of prosthetic memories. This is because their inclusion could have opened up a broader geopolitical contextualization by foregrounding the criminalization of humanitarian organizations and the militarization of EU borders, which could have pushed the visitors further towards acknowledging their own involvement, however remote, in the political situation. The point can be illustrated by a discussion on what was not interpreted in the display of the rubber dinghy.

\section{The dinghy as a controversial object}

Boats have become central symbols in museum exhibitions on migration (Cimoli 2016; Tao 2016) and carry complex meanings as sites of 'both refuge and trauma' (Tao 2016: 54). As pointed out by Karina Horsti, mediated images of boats have, since the 1990s, become 'iconic ways to represent undocumented migration' (Horsti 2016: 83). The constant recirculation of such visual representations is a central instrument in symbolic bordering processes (see also Horsti 2019b).

Encountering a dinghy in the Flight for Life exhibition that was used by refugees in the Mediterranean was a moving experience. The large photograph served to both contextualize it and remind visitors of similar mediated images (Figure 2). At six metres in length, the dinghy was an impressively large museum object. Despite this, visitors might have recognized how vulnerable the refugees could have felt sitting in it while on the open sea. Thus, this particular object may have served to promote solidarity with the refugees, but following Svanberg's multidimensional approach to collected objects, the dinghy 'could be viewed from many perspectives and interpreted in different ways' (Svanberg 2017: 157). In the following paragraphs, additional media will be focused on, in order to connect the dinghy to the donor, who had personally experienced the increased criminalization of humanitarian help.

The inflatable dinghy was donated by Salam Aldeen, a Danish citizen and one of the co-founders of Team Humanity - a Danish volunteer organization founded in September 2015 to collaborate with similar organizations and provide humanitarian assistance to refugees arriving in Lesbos. ${ }^{18}$ Aldeen was born in Moldova, and his family fled to Denmark in 1992 when he was nine years old. The images in the Danish media of Alan Kurdi, a three-year old refugee who drowned in the Mediterranean, prompted Aldeen to travel to Lesbos in order to help and found Team Humanity. Among the activities of the organization were rescue operations at sea.

On a January night in 2016, Aldeen, another Danish Team Humanity volunteer and three Spanish firefighters from another organization were arrested, as the Greek coastguard had accused them of crossing into Turkish territory. They were charged with human trafficking but were all acquitted at a Greek court in May 2018, after having proven that they were only two kilometres from the Greek coast. ${ }^{19}$ This court case received extensive attention from both Danish and international media and was described as an example of the growing tendency of EU member states to use 'laws, aimed at traffickers and smugglers, to criminalize those acting out of humanitarian motives'. ${ }^{20}$ The story of Team Humanity, as well as the personal stories of Aldeen and his fellow volunteers, obviously add other perspectives to the inflatable dinghy. However, these perspectives were not presented in Flight for Life and hence an opportunity to reflect on EU border politics and their relationship to the situation on Lesbos was missed.

The reason this is an important point is that the role played by humanitarian NGOs 
in Greece has been a contentious issue, which, in the Danish context, has led some critics and politicians to question the work of volunteers - sometimes even referring to them as 'traitors' who are harming both Denmark and the European continent. ${ }^{21}$ When the Flight for Life exhibition was on show at the National Museum in spring 2017, Aldeen and the other volunteers were awaiting trial at a Greek court. As mentioned earlier, the object label briefly noted that Team Humanity had used the dinghy to help refugees 'get safely ashore' without mentioning the serious issue of the court hearing. In the fall of 2018, when an adapted version of the Flight for Life exhibition was opened at Moesgaard Museum, a more detailed object label was created. The text developed on the humanitarian aid provided by Team Humanity was as follows:

\begin{abstract}
Rubber dinghy. Danish volunteers founded the humanitarian organisation Team Humanity in 2015. Initially, they worked on Lesbos to engage in rescue operations by the coastline, to hand out essentials, and to provide translators, medical help and more. Later, they shifted their operations to the informal refugee camp Indomeni, in Northern Greece, and then to Oreokastro Camp, near Thessaloniki. In January 2016, the co-founder of Team Humanity, Salam Aldeen, was arrested and charged with human trafficking alongside one Danish and three Spanish colleagues. They were arrested while sailing along the coast of Lesbos in an effort to find two boats filled with refugees, which they had heard were in distress. The five men were finally acquitted in May 2018. Team Humanity has helped save thousands of lives on Lesbos (Exhibition text, Moesgaard Museum).
\end{abstract}

After the trial, the dinghy became less of a sensitive object, and the more detailed object label positioned the volunteers as heroes. This unfolding of the potential meanings of the dinghy exemplifies how timing becomes a pertinent question in the contemporary collecting and exhibiting of contentious issues. However, the Moesgaard Museum still did not place the events of the court case within the broader political context of attempts to criminalize humanitarian actors. In my view, these highly contentious issues of EU bordering politics would be quite difficult to address in a Danish museum exhibition in the current political climate, but leaving them out hindered the museum in realizing the full potential of prosthetic memory as an exhibition strategy, since visitors with Danish/EU citizenship were not confronted with their own responsibility for the EU's actions during the refugee reception crisis.

\title{
Conclusion
}

Museums that choose to collect items and hold exhibitions of undocumented migration in European border zones are navigating dangerous political waters. Acknowledging the difficulties that museums face when engaging with migration and refuge issues, Vlachou has proposed that museums serve as 'empathetic spaces that may help people deal with the discomfort brought about by encountering opposing views' (Vlachou 2019: 54). However, this would imply the need to represent conflicting political views explicitly, and in some situations, the museum in question would simply end up reproducing animosities and failing to offer an alternative to the harsh debates taking place elsewhere in the public sphere. The Flight for Life exhibition at the National Museum of Denmark opened in spring 2017, when political tension regarding arriving refugees was high. In that particular situation, I believe that the museum made a wise choice in refusing to directly enter the political polarization within Danish society. Rather, it adopted a more subdued stance by promoting empathy with the plight of refugees. Drawing on the thoughts of Landsberg, I have shown how the exhibition invited visitors to create prosthetic memories of the refugee reception crisis. The museum claimed a neutral position, but I have argued that the exhibition did have political potential in terms of producing a sense of solidarity with refugees, through identifying with their troubles and choices and thus understanding their motivations for fleeing to Denmark/Europe. However, Landsberg stresses that empathy requires self-reflection and acknowledgement of one's own position. I have argued that the exhibition invites the visitor to realize the safety that follows from holding Danish and/or EU citizenship, but they are not confronted with the political responsibility that follows from this privileged position. 
By focusing on the rubber dinghy, I exemplified how the objects collected could have been used to represent more contentious issues of the refugee reception crisis. The museum could have told the stories of Danes volunteering in Greece and being criminalized for their humanitarian help. Other aspects that were not discussed in the Flight for Life exhibition were the detention centres and forced deportations, both elements of Danish migration policy. However, by including these issues, the museum would have risked alienating large groups of the Danish public and irritating politicians, with potential ramifications for both the museum's reputation and funding. Thus, seen in the context of the Danish political landscape, the museum's relatively 'safe' choices are understandable, but they came with a price in terms of not fully making use of prosthetic memories' potential for prompting critical thinking. In order to do so, the visitors would need to recognize their own connection (at least in their role as voters) to Denmark's and the EU's migration politics.

How will Europe remember the refugee reception crisis of the early twenty-first century? While people and politicians are debating European migration policies and attempting to grasp the ethical aspects of current border politics, Europeans will, in the future, have to come to terms with a period in history that saw the increased militarization of borders, the dehumanization of fleeing people and attempts to criminalize humanitarian action. Our time may be judged by its backlash against human rights and rising xenophobia or, alternatively, as a period when the borders of Europe were successfully protected against a sudden influx of foreigners into Europe. In all probability, different memory discourses will compete, and it would be futile to attempt to predict which of these discourses will dominate in 50-or 100-years' time. Nevertheless, Karina Horsti has rightly highlighted the risk of selective forgetting, which either intentionally or otherwise "hides the ways in which European societies have been implicated in the production of the "crisis"' (Horsti 2019a: 3). Through contemporary collection projects, museums are actively constructing future memory politics, since their collecting strategies will determine how events can be exhibited in the future. The collecting project at the Danish National Museum aimed to document the refugee situation in the 2010s and 'now and in a 100 years'. Temporal distance will - hopefully - enable exhibitions, that more directly include geopolitical and historical explanations, to allow the European public to look back and reflect on national and European migration policies during the early decades of the twenty-first century.

Received: 17 May 2019

Finally accepted: 10 May 2021

\section{Acknowledgements}

This research was carried out as part of the Borderscapes, Memory and Migration explorative workshops, funded by the Joint Committee for Nordic Research Councils in the Humanities and Social Sciences (NOS-HS) during the period 2016-17. The author would like to thank Lise Paulsen Galal and Karina Horsti, as well as two anonymous peer reviewers and an editor at Museum \& Society, for their valuable comments to earlier versions of this article. Furthermore, the author would like to thank Gitte Engholm at the Danish National Museum for providing valuable information about the exhibition.

\section{Disclosure statement}

No potential conflict of interest was reported by the author.

\section{Notes}

1 Gitte Engholm, interview by author, written notes, 20 May 2017, Copenhagen. This interview was followed up by email correspondence, where additional questions were asked.

2 Alex Marshall, 'How the National Museum is Capturing "Instant History" of Abortion Referendum', The Irish Times 21 June 2018. https://www.irishtimes.com/culture/heritage/ how-the-national-museum-is-capturing-instant-history-of-abortion-referendum-1.3537495 accessed 29 February 2020. 
Quoted in Marshall, 'Capturing "Instant History"'.

4 Geraldine Kendall Adams, 'Collecting Drive Gets Underway after Irish Abortion Referendum', Museums Association 30 May 2018. https://www.museumsassociation.org/museumsjournal/news/30052018-collecting-underway-after-irish-referendum, accessed 10 February 2020.

5 Adams, 'Collecting Drive'.

6 The exhibition also included some objects and stories collected by other Danish museums, but their collecting process is beyond the scope of this article.

7 Author's translation from the website of the National Museum of Denmark, Nationalmuseet, 'Særudstilling: På flugt' [Temporary exhibition: Flight for Life]. https://natmus.dk/salg-ogydelser/museumsfaglige-ydelser/vandreudstillinger/paa-flugt/ accessed 23 November 2018.

8 Author's translation from the website of the National Museum of Denmark.

9 Some commentators described the recent cutbacks of 20 per cent of the funding of the Danish public service broadcaster, Danmarks Radio, as a revenge strategy of the DF (Jensen 2018). The party had been critical of the television station's representation of national history in drama and documentary series.

10 Folders with exhibition texts in Arabic, English and Farsi were available at the exhibition's entrance, and postcards with the exhibition title in Arabic, English and Farsi were used to promote the exhibition.

11 The author's analysis quotes the exhibition texts in the English folder combined with the author's own translations of the Danish object labels, which were not included in the folder.

12 The following analysis examines the representational strategies used in the Flight for Life exhibition and does not study the extent to which the exhibition succeeded in creating prosthetic memory and challenging xenophobic stereotypes among actual visitors. These questions of audience research are unfortunately beyond the scope of this article. See Horsti (2019b) for a discussion of refugees' reactions to similar exhibitions.

13 Randi Marselis, 'Prosthetic Memories of a Refugee Route', Border Criminologies 13 June 2017. https://www.law.ox.ac.uk/research-subject-groups/centre-criminology/centrebordercriminologies/blog/2017/06/prosthetic, accessed 10 February 2020.

14 The photograph was taken by Yannis Behrakis, the award-winning Greek photographer, and was also used in the poster for the exhibition.

15 'Jan', interview by Madeleine Kate McGowan and Laura Vilsgaard, Other Story, October 2015, Lesbos, Greece.

16 I here refer to everyday conversations with Danish relatives and acquaintances.

17 The video footage was provided by the Austrian artist, Tanja Boukal, and is part of her Aegarian Project. The video footage has not been added permanently to the collection of the National Museum of Denmark. Project website: 'The Aegean Project', http://www. boukal.at/en/the-aegean-project, accessed 20 November 2018.

18 The organization has, since spring 2016, been working at various refugee camps in Greece. The description of Team Humanity's activities and related events can be found on the organization's website as well as on a number of Danish and international news reports (e.g. Abrahamsen 2015; Niki Kitsantonis 'Volunteers who Rescued Migrants are Cleared 
of Criminal Charges in Greece', The New York Times 7 May 2018. https://www.nytimes. com/2018/05/07/world/europe/greece-migrants-volunteers. html accessed 20 November 2018; Jeppe Krogager and Peter Møller, 'Dansker anklaget for menneskesmugling i over to år - nu falder dommen' [Dane Accused of Human Trafficking for More than Two Years - Now the Sentence is Pronounced], TV2/Nyheder 5 May 2018. http://nyheder.tv2.dk/ udland/2017-05-11-dansker-maa-ikke-forlade-graekenland-det-begyndte-med-et-raabom-hjaelp accessed 20 November 2018; Rawan Radwan, “'I Don't Smuggle People ... I Save Them", Migrant Rescue Leader Says After Being Acquitted of Human Trafficking', Arab News 22 May 2018. http://www.arabnews.com/node/1307141/world. accessed 20 November 2018). http://teamhumanity.eul, accessed11 February 2020.

19 According to one news article, they were able to prove their position with data from their mobile phones (Krogager and Møller, 'Dansker anklaget for menneskesmugling').

Institute of Race Relations, 'EU Member States, in Criminalising Humanitarians, are Feeding Europe's Far Right' [press release], 11 November 2017, para. 1. http://www.irr.org. uk/news/eu-member-states-in-criminalising-humanitarians-are-feeding-europes-far-right/, accessed 20 November 2018; see also Tim Baster and Isabelle Merminod, 'Humanitarian Workers Acquitted of "Crime" of Helping Refugees', New Internationalist 10 May 2018. https://newint.org/features/web-exclusive/2018/05/10/humanitarian-workers-acquitedhelping-refugees, accessed 20 November 2018.

21 Politicians from the DF have voiced such opinions in Danish media, including during a debate on public service radio (Danmarks Radio 2018).

\section{References}

Abrahamsen, S. (2015) 'De bredeste skuldre på stranden' [The Broadest Shoulders on the Beach], Information, 14 May, 8.

Arnold-de Simine, S. (2013) Mediating Memory in the Museum: Trauma, Empathy, Nostalgia, Basingstoke: Palgrave Macmillan.

Berger, J. (2007) 'Which Prosthetic? Mass Media, Narrative, Empathy, and Progressive Politics', Rethinking History, 11 (4) 597-612.

Cimoli, A.C. (2016) 'Identity, Complexity, Immigration: Staging the Present in Italian Migration Museums', in Christopher Whitehead, Katherine Lloyd, Susannah Eckersley and Rhiannon Mason (eds) Museums, Migration and Identity in Europe: Peoples, Places and Identities, 285-315, New York: Routledge.

Colding, E., Engholm, G. and Clausen, R. (2018) 'Route 360, New Roads for Communication: Imaginative and Didactic Faculties in Visual Technology', Anthrovision, 6 (1) 1-19.

Crooke, E. (2019) 'Memory Politics and Material Culture: Display in the Memorial Museum', Memory Studies, 12 (6) 617-29.

Danmarks Radio (2018) 'P1 debat: flygtninge svigt?' [P1 Debate: Refugee Fail?], P1 Debat [P1 Debate] [Radio programme], 13 June.

De Angelis, A. (2013) 'A Museum on the Margins of the Mediterranean: Between Caring for Memories and the Future', in Beatrice Ferrara (ed) Cultural Memory, Migrating Modernities and Museum Practices, 35-44, Politecnico di Milano, Milan: Mela Books. 
Dudley, S.H. (2010) 'Museum Materialities: Objects, Sense and Feeling', in Sandra H. Dudley (ed) Museum Materialities: Objects, Engagements, Interpretations, 1-17, London: Routledge.

Engholm, G., Christensen, L.K. and Møller, K.G. (2018) 'På flugt - en udstilling baseret på samtidsdokumentation' [Flight for Life - An Exhibition based on Contemporary Collecting], in Per Kristian Madsen and Ingrid Wass (eds) Nationalmuseets Arbejdsmark 2018, 24-37, Copenhagen: Nationalmuseet.

Fraser, P. (2014) 'The Memorial and the Museum: Strathewen's Poetry Tree', in Owain Rhys and Zelda Baveystock (eds) Collecting the Contemporary: A Handbook for Social History Museums, 406-39, Edinburgh: MuseumsEtc.

Horsti, K. (2016) 'Imagining Europe's Borders: Commemorative Art on Migrant Tragedies', in Lynda Mannik (ed) Migration by Boat: Discourses of Trauma, Exclusion and Survival, 83-100, New York: Berghahn Books.

(2019a) 'Introduction: Border Memories', in Karina Horsti (ed) The Politics of Public Memories of Forced Migration and Bordering in Europe, 1-14, Cham: Palgrave Macmillan.

(2019b) 'Curating Objects from the European Border Zone: The "Lampedusa Refugee Boat"', in Karina Horsti (ed) The Politics of Public Memories of Forced Migration and Bordering in Europe, 53-70, Cham: Palgrave Macmillan.

Jensen, L. (2018) 'Medieforliget blev DF's hævn' [The Media Agreement Became the Revenge of the Danish People's Party], Information, June 30, back page.

Kavanagh, J. (2014) 'Collecting Challenging Contemporary History: Terrorist Attacks in London and New York City', in Owain Rhys and Zelda Baveystock (eds) Collecting the Contemporary: A Handbook for Social History Museums, 446-75, Edinburgh: MuseumsEtc.

Kopytoff, I. (1986) 'The Cultural Biography of Things: Commoditization as Process', in Arjun Appadurai (ed) The Social Life of Things: Commodities in Cultural Perspective, 64-91, Cambridge: Cambridge University Press.

Landsberg, A. (2004) Prosthetic Memory: The Transformation of American Remembrance in the Age of Mass Culture, New York: Columbia University Press.

(2007) 'Response', Rethinking History, 11 (4) 627-9.

Marker, L. and Rasmussen, M. (2019) Museumslandskabet: Kulturpolitikkens udvikling and museernes vilkår [The Museum Landscape: Developments in the Culture Policy and the Conditions of the Museums], Copenhagen: Rasmussen \& Marker.

Marselis, R. (2016) 'On Not Showing Scalps: Human Remains and Multisited Debate at the National Museum of Denmark', Museum Anthropology 39 (1) 20-34.

Nikolić, D. (2017) 'The Future is Ours', in Christina Johansson and Pieter Bevelander (eds) Museums in a Time of Migration: Rethinking Museums' Roles, Representations, Collections, and Collaborations, 197-222, Lund: Nordic Academic Press.

Pratt, M.L. (2008) Imperial Eyes: Travel Writing and Transculturation, 2nd edition, London: Routledge.

Rhys, O. (2011) Contemporary Collecting: Theory and Practice, Edinburgh: MuseumsEtc. 
Rhys, O. and Baveystock, Z. (eds) (2014) Collecting the Contemporary: A Handbook for Social History Museums, Edinburgh: MuseumsEtc.

Stockmann, C. (2016) 'Nationalmuseet indsamler genstande fra syriske flygtninge' [The National Museum Collects Objects from Syrian Refugees], Politiken, Kultur, 3 May, 3.

Svanberg, F. (2017) 'From Totality to Infinity: Reimagining Museum Collecting', in Christina Johansson and Pieter Bevelander (eds) Museums in a Time of Migration: Rethinking Museums' Roles, Representations, Collections, and Collaborations, 155-68, Lund: Nordic Academic Press.

Tao, K. (2016) 'Representing Migration by Boat at the Australian National Maritime Museum', in Lynda Mannik (ed) Migration by Boat: Discourses of Trauma, Exclusion and Survival, 49-64, New York: Berghahn Books.

Termansen, V. (2017) 'Over vandet' [Above the water], Weekendavisen, 20 May, 5.

Vlachou, M. (2019) 'Dividing Issues and Mission-driven Activism: Museum Responses to Migration Policies and the Refugee Crisis', in Robert R. Janes and Richard Sandell (eds) Museum Activism, 47-57, London: Routledge.

\section{Author}

Randi Marselis

Associate Professor, PhD, Department of Communication and Arts, Roskilde University, Denmark

Postal Adress:

Randi Marselis

Department of Communication and Arts

Roskilde University

Universitetsvej 1, Postboks 260

4000 Roskilde

Denmark

Email: marselis@ruc.dk

ORCID ID: orcid.org/0000-0003-1894-6462

Randi Marselis is Associate Professor in Cultural Encounters at the Department of Communication and Arts, Roskilde University, Denmark. Her research examines European memory politics in relation to migration and postcolonial history. She is particularly interested in the potential of museums for creating inclusive memory cultures that acknowledge the cultural heritage of migrant communities. Furthermore, her research examines the role of digitization and social media genres in the remediation of colonial history and migrant heritage. 